\title{
Study of goat milk and goat milk yogurt to decrease parasitemia index on malaria-infected mice
}

\author{
${ }^{1}$ Sada, M., ${ }^{2}$ Legowo, A.M. and ${ }^{3, *}$ Anjani, G. \\ ${ }^{1}$ Sorong Health Polytechnic of Health Ministry, Indonesia \\ ${ }^{2}$ Department of Food Technology, Faculty of Animal and Agricultural Sciences, Diponegoro University, \\ Semarang, Indonesia \\ ${ }^{3}$ Department of Nutrition Science, Faculty of Medicine, Diponegoro University, Semarang, Indonesia
}

Article history:

Received: 31 January 2020

Received in revised form: 15

April 2020

Accepted: 17 May 2020

Available Online: 30 May

2020

\section{Keywords:}

Malaria,

Parasitemia index,

Goat milk,

Goat milk yogurt

\section{DOI:}

https://doi.org/10.26656/fr.2017.4(S3).S26

\begin{abstract}
Malaria is an infectious disease caused by the Plasmodium sp. parasite. In 2017, malaria has reached 219 million cases. The decline of parasitemia index indicates a lower degree of infection in malaria patients. Goat milk and goat milk yogurt as immunomodulators have the potential to reduce parasitemia index. This study was aimed to determine the effect of goat milk and goat milk yogurt on the index of parasitemia in malaria-infected mice. This research was a true experimental study with a post-test only group design. A total of thirty-five female Balb/c mice was divided into the following groups: a (negative control group), b (malaria), c (malaria, Dihydroartemisinin/piperaquine (DHP) drug), d (malaria, goat milk), e (malaria, goat milk, DHP), f (malaria, goat milk yogurt), and $\mathrm{g}$ (malaria, goat milk yogurt, DHP). Inoculation dose of Plasmodium was $10^{7} / 0.2 \mathrm{~mL}$. The intervention was studied for 24 days. Parasitemia index data was collected on the seventh day post-inoculation. The dose of goat milk and goat milk yogurt given was $0.5 \mathrm{~mL} / 20 \mathrm{~g}$ BW. Data were analyzed using Kruskal-Wallis with Mann-Whitney post-hoc test. The results showed a significant decrease in the parasitemia index $(p<0.05)$. The mean parasitemia index in each group were: $0 \%$ (a); $13.9 \%$ (b); $0.60 \%$ (c); $4.68 \%$ (d); $3.74 \%$ (e); $3.66 \%(\mathrm{f}) ; 0.82 \%(\mathrm{~g})$. The group that exhibited effective reduction of parasitemia index were group c and g. Goat milk yogurt (f) was more effective in decreasing the parasitemia index than goat milk (d). Giving goat milk yogurt can be considered an additional therapy for the treatment of malaria.
\end{abstract}

\section{Introduction}

Malaria is a disease caused by a protozoan parasite from the genus Plasmodium (Percário et al., 2012; Khalid et al., 2013; Isah and Ibrahim 2014; Okpe et al., 2016). Malaria is transmitted by the bite of a female Anopheles mosquito that carries the Plasmodium (Mota et al., 2019; Mala et al., 2016). The type of Plasmodium that is responsible for most cases of malaria in tropical and subtropical regions is Plasmodium falciparum (Emmanuel et al., 2016). Plasmodium infection from malaria will cause oxidative changes and an imbalance of antioxidant mechanisms. (Khalid et al., 2013; Fabbri et al., 2013; Gomes et al., 2015). Malaria infection increases parasitemia index, an indicator of the severity of infection in malaria patients (Tyagi et al., 2017). The use of antioxidants is expected to help reduce oxidative damage and prevent further development of malaria (Gomes et al., 2015).
Goat milk is known for its positive effects on the biological functions of the human body due to its nutritional content. Goat milk also has low allergen levels and is easily digested by the body (Yangilar, 2013; Aristya et al., 2013; Banjare et al., 2017). Furthermore, it contains natural antioxidant-forming agents which can prevent the lysis of erythrocyte cells (Alyaqoubi et al., 2015). Protein in goat milk is the main source of active biopeptides that can act as antioxidants (Park, 2010: Alyaqoubi et al., 2014; Alyaqoubi et al., 2014). In addition, it demonstrates anti-inflammatory properties and serves as an important source of angiotensinconverting enzyme (ACE) which functions as an antihypertensive peptide and helps alleviate infections caused by pathogenic microbes (Lad et al., 2017).

Goat milk can be processed and fermented into yogurt. Yogurt contains bioactive peptides and has antioxidant activity (Gahruie et al., 2015; Nguyen and 
Hwang, 2016). The antioxidant activity of goat milk yogurt is known to be higher than cow milk yogurt (Holvik, 2013; Muniandy et al., 2016). Increased antioxidant properties in goat milk yogurt results from the activity of lactic acid bacteria (LAB). Several studies have reported the effects of $\mathrm{LAB}$ in response to oxidative stress (Fardet and Rock, 2017; Shu et al., 2018; MorenoFernandez et al., 2019). The potential health benefits of LAB includes stimulating the immune system, maintaining the balance of the intestinal flora, reducing cholesterol levels, and promoting anti-aging and antioxidant activity (Nakagawa and Miyazaki, 2016). LAB produces exopolysaccharides (EPS) which specifically has immunostimulant activity and increases the digestive tract colonization (Polak-Berecka et al., 2013). LAB hydrolyzes casein into a bioactive peptide with various biological functions. Based on previous researches, casein in goat milk yogurt is capable of preventing the increase of Malondialdehyde (MDA) levels (Mahdi et al., 2018). This study is aimed to determine the effects of consuming goat milk and goat milk yogurt on the parasitemia index of mice infected with malaria. This research is expected to be useful in the development of food and health science in relation to the role of antioxidants in the treatment of malaria.

\section{Materials and methods}

\subsection{Inoculation Plasmodium berghei ANKA (PbA)}

This research used female Balb/c mice that have been inoculated with Plasmodium berghei ANKA ( $\mathrm{PbA})$. Three donor mice were obtained from the parasitology laboratory of the Faculty of Medicine, Nursing and Public Health, Gadjah Mada University (FKKMK UGM). Each mouse was inoculated with $10^{7} \mathrm{~mL}$ of $\mathrm{PbA}$ parasite that was given at $0.2 \mathrm{~mL}$ intraperitoneally (Tafor et al., 2013)

\subsection{Animal and treatments}

The research design used in this research is true experimental with random post-test controlled group. Infected mice were divided into 7 groups: 3 control groups and 4 treatment groups. Group A (negative control group fed with normal food); group B (positive control group fed with normal food, inoculated with $\mathrm{PbA}$ and not receiving treatment); group $\mathrm{C}$ (positive control group with normal food, inoculated with $\mathrm{PbA}$ and given the anti-malaria therapy (DHP)); group D (treatment group 1, inoculated with $\mathrm{PbA}$ and given goat milk); group $\mathrm{E}$ (treatment group 2, inoculated with $\mathrm{PbA}$, given the anti-malaria therapy (DHP) and goat milk); group F (treatment group 3, inoculated with $\mathrm{PbA}$ and given goat milk yogurt); group $\mathrm{G}$ (treatment group 4, inoculated with $\mathrm{PbA}$, given the anti-malaria therapy (DHP) and goat milk yogurt).

Parasitemia index data was collected at the $7^{\text {th }}$ day post-inoculation. The goat milk and goat milk yogurt dose are $0.5 \mathrm{~mL} / 20 \mathrm{~g} \mathrm{BW}$. The DHP dose used the combination of $3 \mathrm{mg} / \mathrm{kg}$ BW/days of Dihydroartemisinin and $24 \mathrm{mg} / \mathrm{kg} \mathrm{BW} /$ day of Piperaquinine (Ariani et al., 2018).

Yogurt production as well as analysis of protein content and antioxidant activity of goat milk and goat milk product was done at the Integrated Laboratory of Diponegoro University, Semarang. Animal experiments including malaria inoculation and parasitemia index measurement were performed in Integrated Biomedic Laboratory (IBL) Medical Faculty of Sultan Agung Moeslem University Semarang (FK-UNISSULA). Goat milk was obtained from Kuncen Farmer Group at Bubakan Village, Mijen Semarang.

\subsection{Goat Milk Yogurt Preparation}

Before the yogurt making process, subculture starter was made to activate the Lactic Acid Bacteria (LAB) in commercial starter (manufactured yogurt). The manufactured yogurt contained Streptococcus thermophiles culture, Lactobacillus bulgaricus, Lactobacillus acidophilus, and Bifidobacterium.

About $16 \mathrm{~g}$ of skim milk was dissolved in $100 \mathrm{~mL}$ goat milk and pasteurized at $75^{\circ} \mathrm{C}$ for $15 \mathrm{~s}$. Next, the milk was mixed with commercial starter (manufactured yogurt) at the ratio of $1: 1$ and incubated at $40^{\circ} \mathrm{C}$ for 24 hours.

Goat milk yogurt production used $500 \mathrm{~mL}$ fresh goat milk. Goat milk was pasteurized at $75^{\circ} \mathrm{C}$ for $15 \mathrm{~s}$ and later cooled down until $43^{\circ} \mathrm{C}$. Afterwards, the mixture was incubated with bacteria starter made from $5 \%$ fresh goat milk and incubated at $42^{\circ} \mathrm{C}$ for $6 \mathrm{hrs}$ before it was cooled in room temperature. Prepared yogurt was packed and kept in the refrigerator.

\subsection{Goat milk and goat milk yogurt intervention}

Goat milk and goat milk yogurt was given orally using feeding tube (sonde). The dose was determined based on the maximum capacity of the mice stomach which was $1 \mathrm{~mL} / 20 \mathrm{~g}$ BW (Ngatidjan, 2006). Ideal amount is $0.25-0.5 \mathrm{~mL}$ and the given amount in this research was $0.5 \mathrm{~mL} / 20 \mathrm{~g} \mathrm{BW} /$ day. The goat milk and goat milk yogurt were given for 24 days, consisting of 21 days pre-inoculation and 3 days post-inoculation.

\subsection{Parasitemia index examination}

Object glass was thoroughly cleaned and coded in the top right corner. Blood sample was dropped on the 
object glass to make a smear that was repetitively washed and dried before applied with Giemsa stain. Samples were examined under the microscope with a $10 \times 10$ visual field enlargement, then 10x100 enlargement with immerse oil. Parasite erythrocytes were calculated and stated in percentage and compared with the studied blood (Torres et al., 2018).

\subsection{Statistical analysis}

The results were described as median $\pm \mathrm{SD}$ (for normally distributed data) or median (min-max) if otherwise. The statistical difference was analyzed using Kruskall Wallis and Mann Whitney Post-hoc test.

\subsection{Ethical clearance}

This research was approved by the Health Research Ethics Commission of the Sultan Agung University School of Medicine with No. 196/III/2019/Biocommission.

\section{Results}

A total of 28 mice were obtained from the Biology Laboratory of Semarang State University with 25 for treatment and 3 as donor mice. The results of normality test of parasitemia index using the Saphiro-Wilk test obtained $p$-value $<0.005(\mathrm{p}=0.00)$, indicating that the parasitemia index data was not normally distributed thus the Kruskal-Wallis test was performed. Based on Table 1 , there is a statistically significant difference in the parasitemia index $(\mathrm{p}<0.05)$. Next, Post Hoc tests were carried out with Mann-Whitney and the results are as seen in Table 1. Treatment by giving goat milk and goat milk yogurt or a combination of both with DHP drugs has been proven to positively affect the parasitemia index.

Based on Table 1, the groups with no significant

Table 1. Statistical analysis of the parasitemia index difference on the parasitemia index were the $\mathrm{c}$ and $\mathrm{g}$ groups with a value of $p=0.289$. In the $d$ and e groups, there was also no significant difference in the parasitemia index with a value of $p=0.059$. Similarly, group $\mathrm{d}$ and group $\mathrm{f}$ also showed no significant difference with a value of $p=0.602$. These results indicate that the two groups did not have different effectiveness in suppressing the parasitemia index. The ability of each group to suppress the parasitemia index can be seen based on the average parasitemia index in Figure 1.

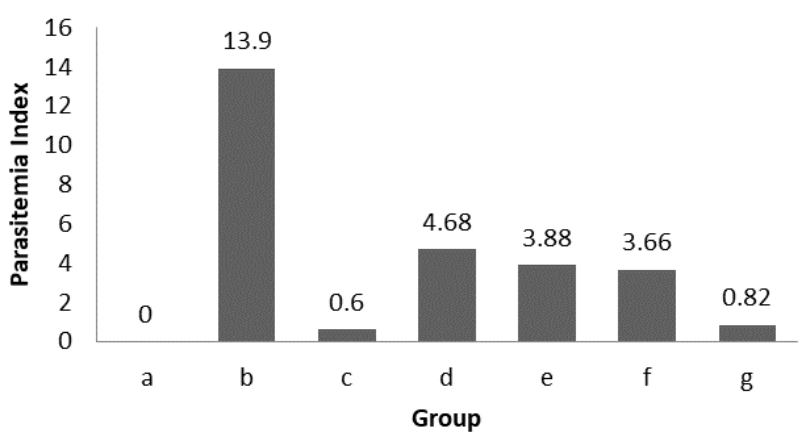

Figure 1. Average parasitemia index results. $\mathrm{a}=$ Negative Control Group, Healthy; $b=$ Positive Control Group, Malariainfected; $\mathrm{c}=$ Control Group, Malaria-infected and DHP Drug Administration; $\mathrm{d}=$ Treatment Group, Goat milk - Malariainfected - Goat milk; e = Treatment Group, Goat milk Malaria-infected - Goat milk and DHP; $\mathrm{f}=$ Treatment Group, Goat milk Yogurt - Malaria-infected - Goat milk Yogurt; g = Treatment Group, Goat milk Yogurt - Malaria-infected - Goat milk Yogurt and DHP.

\section{Discussion}

Malaria is one of the endemic diseases in Indonesia which is still a major health concern. Malaria is usually treated with antimalarial drugs. Standard treatment for malaria uses Artemisinin-based combination therapies (ACTs). These therapies can combine artemisinin or one of its derivatives with another antimalarial drug. One of

\begin{tabular}{ccccccccccc}
\hline \multirow{2}{*}{$\begin{array}{c}\text { Treatment } \\
\text { Group }\end{array}$} & $\begin{array}{c}\text { Parasitemia } \\
\text { index (\%) }\end{array}$ & \multirow{2}{*}{$P^{l}$} & \multicolumn{8}{c}{$P^{2}$} \\
\cline { 4 - 10 } & & $\mathrm{a}$ & $\mathrm{b}$ & $\mathrm{c}$ & $\mathrm{d}$ & $\mathrm{e}$ & $\mathrm{f}$ & $\mathrm{g}$ \\
\hline $\mathrm{a}$ & $0.00 \pm 0.00$ & & - & $0.005^{*}$ & $0.005^{*}$ & $0.005^{*}$ & $0.005^{*}$ & $0.005^{*}$ & $0.005^{*}$ \\
$\mathrm{~b}$ & $13.9 \pm 0.58$ & & - & - & $0.009^{*}$ & $0.009^{*}$ & $0.009^{*}$ & $0.009^{*}$ & $0.009^{*}$ \\
$\mathrm{c}$ & $0.60 \pm 0.27$ & & - & - & - & $0.009^{*}$ & $0.009^{*}$ & $0.009^{*}$ & 0.289 \\
$\mathrm{~d}$ & $4.68 \pm 0.53$ & $0.00^{*}$ & - & - & - & - & 0.059 & 0.602 & $0.008^{*}$ \\
$\mathrm{e}$ & $3.74 \pm 0.74$ & & - & - & - & - & - & 0.834 & $0.005^{*}$ \\
$\mathrm{f}$ & $3.60 \pm 1.80$ & & - & - & - & - & - & - & $0.008^{*}$ \\
$\mathrm{~g}$ & $070(0.70-1.20)$ & & - & - & - & - & - & - & - \\
\hline
\end{tabular}

${ }^{1}=$ Kruskall Wallis, ${ }^{2}=$ Post Hoc Mann-Whitney, ${ }^{*}=\mathrm{p}$ value $<0.005$ (significantly)

$\mathrm{a}=$ Negative Control Group, Healthy; $\mathrm{b}=$ Positive Control Group, Malaria-infected; $\mathrm{c}=$ Control Group, Malaria-infected and DHP Drug Administration; $d$ = Treatment Group, Goat milk - Malaria-infected - Goat milk; e = Treatment Group, Goat milk Malaria-infected - Goat milk and DHP; $\mathrm{f}=$ Treatment Group, Goat milk Yogurt - Malaria-infected - Goat milk Yogurt; $g=$ Treatment Group, Goat milk Yogurt - Malaria-infected - Goat milk Yogurt and DHP. 
the combinations is Dihidroartemisinin Piperaquin (DHP). Papua and West Papua are regions in Indonesia that are still endemic for malaria (Subdit Malaria Direktorat KR, 2018). When malaria cases occur, not all patients have immediate access to health facilities and DHP medication as early as possible. Utilization of functional food is considered to be an additional therapy for malaria patients. One of the functional foods that can be developed is goat milk and goat milk yogurt (Yangilar, 2013).

This research aimed to determine the effect of goat milk and goat milk yogurt in decreasing parasitemia index. The results of this research can be seen in Figure 1. Figure 1 shows that the group with the lowest parasitemia index is group a (negative control group, healthy) with $0 \%$ because they were not inoculated with malaria. Group b (positive control group, malariainfected) had the highest parasitemia index among all groups $(13.9 \%)$ as they were inoculated with malaria and not given any treatment thus the Plasmodium continued to multiply and the parasitemia index increased. Group c (malaria-infected, DHP drug administration) $(0.6 \%)$ was found to have the lowest mean of parasitemia index compared with other groups, further proving the effectiveness of the use of DHP drugs. DHP drugs include an artemisinin group that is known to be effective in killing Plasmodium quickly in all life stages including gametocytes (Douglas et al., 2010).

The mean parasitemia index values in groups $d$ (malaria-infected, given goat milk) and $\mathrm{f}$ (malariainfected, given goat milk yogurt) were lower compared with group $b$, suggesting that goat milk yogurt may play a role in lowering parasitemia index. Goat milk and goat milk yogurt both contain casein and whey which has been shown to possess antioxidant activity (Sabeena et al., 2010). Casein can work as radical scavengers and cation chelators which can inhibit lipid oxidation. In goat milk yogurt, the components of whey protein consisting of lactoferrin, beta-lactoglobulin, alpha-lactalbumin, glyomropropeptides, and immunoglobulins can boost the immune system. Lactoferrin binds the iron in the intestinal mucosa and acts as a bacteriostatic agent by suppressing populations of harmful bacteria and modulating the body's immunity. Lactoferrin also repairs cell damage by inhibiting the production of ROS and works with vitamin $\mathrm{E}$ in limiting membrane lipid oxidation by ROS. $\beta$-Lactoglobulin plays a role in the transfer of pro-vitamin $\mathrm{A}$, while $\alpha$-Lactalbumin is involved in lactose synthesis. Immunoglobulin is important for an antigen-antibody reaction. This protein component can enhance the immune system. The major protein boosts the immune system by converting the cysteine intracellular amino acids into glutathione that acts as an intracellular antioxidant. Lactoferrin provided in goat milk and goat milk yogurt can stimulate the immune system through the activation of $\mathrm{T}$ and $\mathrm{B}$ lymphocyte cells (Queiroz et al., 2013; Zapata et al., 2017; Mahdi et al., 2018).

Group f (malaria-infected, given goat milk yogurt) was more effective in reducing the parasitemia index than group d (malaria-infected, given goat milk). Yogurt generally contains lactic acid bacteria that have Bile Salt Hydrolase (BSH) enzyme. BSH is known to be able to de-conjugate bile salts into free bile salts that are less absorbable by the small intestine, leading to reduced amount of bile salts returning to the liver. Consequently, cholesterol would be used as a precursor to balance the amount of bile salt so overall cholesterol levels would decrease. Lower cholesterol levels meant less amount of lipid exposed to free radicals, resulting in decreased lipid peroxidation and eventually a decline in MDA levels and parasitemia index (El-Dein et al., 2017).

The mean parasitemia index of group e (malariainfected, given the anti-malaria therapy and goat milk) and $\mathrm{g}$ (malaria-infected, given the anti-malaria therapy and goat milk yogurt) were higher than group b. This finding supports the contribution of food sources of protein (goat milk or goat milk yogurt) as an effective adjuvant treatment in the treatment of malaria. Giving goat milk or goat milk yogurt alongside DHP drugs was found to be more effective in reducing the parasitemia index. Interestingly, the mice receiving DHP and goat milk yogurt experienced a more significant reduction of parasitemia index than the group receiving DHP and goat milk. The administration of DHP drugs is recommended to be consumed together with milk or fatty foods (WHO, 2015) but previous studies have shown that the administration of DHP drugs together with $200 \mathrm{~mL}$ of milk (containing 6.4 grams of fat) did not improve pharmacokinetic parameters (including absorption of DHP drugs) when compared with the control group (Annerberg et al., 2011). Giving goat milk with DHP drugs might inhibit the bioavailability of the drug because goat milk contains higher calcium and magnesium than cow milk (Park, 2010). Calcium and magnesium have divalent ionic bonds which may inhibit drug absorption (Bushra et al., 2011). On the other hand, administration of DHP with goat milk yogurt can decrease the parasitemia index better than goat milk, making it a more favorable option for malaria adjuvant therapy. The decrease in parasitemia index is due to the content of lactic acid bacteria in goat milk yogurt which may affect intestinal microbiota profile. In accordance with previous studies, intestinal microbiota influenced the pathogenesis of malaria and altering the intestinal bacterial community affected the parasitic load and death 
risk after Plasmodium infection. Providing yogurt helped modulate the intestinal microbiota so that it can reduce the burden of parasites (Villarino et al., 2016).

Yogurt is made by fermentation that causes the release of bioactive peptides from the major protein of milk. The fermentation process produced antioxidant peptides consisting of 5-11 hydrophobic amino acids which include proline, histidine, tyrosine or tryptophan. These amino acids prevent the formation of free radicals and inhibit the process of lipid peroxidation. Lactic acid bacteria exhibit antioxidant activity through suppressing the accumulation of ROS during the food digestion process and destroying superoxide anions and hydrogen peroxide (Gjorgievski, 2015).

Giving goat milk yogurt was proven to help reduce the parasitemia index in our study. One potential mechanism to explain this finding is that intestinal microbiota influenced the severity of malaria by giving a direct effect on the parasite itself, where the products of intestinal microbiota inhibit the growth of parasites. Another potential mechanism is that intestinal microbiota may have modulated the host immune response to Plasmodium. Previous researches showed that intestinal microbiota may send signals for monocytes/macrophages to respond to and control the infection (Denny, 2018).

An important mechanism of yogurt during Plasmodium infection is through the ability of intestinal microbiota to express the glycemic molecule in the form of $\alpha$-gal (Gall $\alpha 1-3 \mathrm{Gal} \beta 1-4 \mathrm{GlnAc}-\mathrm{R}$ ). The $\alpha$-gal antibody binds to the surface of the sporozoite, induces lysis order and prevents the spread of Plasmodium to liver cells. The administration of yogurt can trigger an $\alpha$ gal response to inhibit the transmission of Plasmodium sporozoite (Burgess et al., 2017). The decreased parasitemia index after malaria inoculation implied that diet (intake) played an important role in shaping the composition and activity of intestinal microbiota. Based on previous studies, Lactobacillus and Bifidobacterium have a protective role by modulating the burden of parasites and reducing the severity of malaria. Therefore, the administration of yogurt containing Lactobacillus bacteria can cause a decrease in parasitemia. Changes in intestinal microbiota can prevent malaria severity and accelerate the healing process of malaria. These results also support the possibility that altering the intestinal microbiota profile by giving goat milk yogurt cannot prevent malaria but has the potential to control the severity of malaria in humans (Shasteen et al., 2015).

\section{Conclusion}

The addition of yogurt and DHP resulted in higher parasitemia index in malaria-infected mice in comparison with DHP-only treatment, but the mechanism is unknown. The addition of goat milk yogurt is more effective in lowering the parasitemia index than goat milk only. The administration of goat milk yogurt at a dose of $0.5 \mathrm{~mL} / 20 \mathrm{~g}$ BW can be considered an additional therapy in the treatment of malaria.

\section{Conflict of interest}

The authors declared that they have no competing interests.

\section{Acknowledgments}

This research was funded by the Agency of Health Human Resources Development and Empowerment as a part of Ministry of Health Republic Indonesia. Public health office Jayapura City contributed the Dihydroartemisinin/piperaquine (DHP) drug.

\section{References}

Alyaqoubi, S., Abdullah, A. and Addai, Z.R. (2014). Antioxidant activity of goat milk from three different locations in Malaysia. AIP Conference Proceedings, 1614, 198. https://doi.org/10.1063/1.4895195

Alyaqoubi, S., Abdullah, A., Samudi, M., Abdullah, N., Radhi, Z. and Al-ghazali, M. (2014). Effect of Different Factors on Goat milk Antioxidant Activity Ministry of Regional Municipalities and Water Resource. International Journal of Chem Tech Research, 6(5), 974-4290. http:// sphinxsai.com/2014/vol6pt5/9/(3191-3196)S-

2014.pdf.

Alyaqoubi, S., Abdullah, A., Samudi, M., Abdullah, N., Addai, Z.R. and Al-ghazali, M. (2015). Physicochemical properties and antioxidant activity of milk samples collected from five goat breeds in Malaysia. Advance Journal of Food Science and Technology, 7(4), 235-241. https://doi.org/10.19026/ ajfst.7.1301

Annerberg, A., Lwin, K.M., Lindegardh, N., Khrutsawadchai, S., Ashley, E., Day, N.P., Singhasivanon, P., Tarning, J., White, N.J. and Nosten, F. (2011). Small Amount of Fat Does Not Affect Piperaquine Exposure in Patients with Malaria. Antimicrobial Agents and Chemotherapy, 55, 3971-3976. https://doi.org/10.1128/AAC.0027911

Ariani, Anjani, G., Achasan, M.A.S. and Djamiatun, K. (2018). Tepung ulat sagu (Rhyinchophorus ferrugineus) imunomodulator Nitric Oxide (NO) sirkulasi mencit terapi antimalaria standar. Jurnal Gizi Indonesia, 6(2), 131-138. [In Bahasa 
Indonesia]. https://doi.org/10.14710/jgi.6.2.131-138

Aristya, A.L., Legowo, A.M. and Al-baarri, A.N. (2013). Karakteristik fisik, kimia, dan mikrobiologis kefir susu kambing dengan penambahan jenis dan konsentrasi gula yang berbeda. Jurnal Aplikasi Teknologi Pangan, 2(3), 139-143. [In Bahasa Indonesia].

Banjare, K., Kumar, M., Kumar, R. and Kartikyen, S. (2017). Perspective role of goat milk and products : A review. International Journal of Chemical Studies, 5(4), 1328-1338.

Burgess, S.L., Gilchrist, C.A., Lynn, T.C. and Petri, W.A. (2017). Parasitic Protozoa and Interactions with the Host Intestinal Microbiota. Infection and Immunity, $\quad 85, \quad 1-12 . \quad$ https://doi.org/10.1128/ IAI.00101-17.

Bushra, R., Aslam, N. and Khan, Y.A. (2011). FoodDrug Interactions. Oman Medical Journal, 26(2), 77 83. https://doi.org/10.5001/omj.2011.21

Denny, J.E. (2018). Characterizing the gut microbiota during plasmodium infection and antimalarial treatment. USA: University of Louisville, $\mathrm{PhD}$ Thesis. https://doi.org/10.18297/etd/3109

Douglas, N.M., Ansley, N.M., Angus, B.J., Nosten, F. and Price, R.N. (2010). Artemisinin combination therapy for vivax malaria?. Lancet Infectious Diseases, 10(6), 405-416. https://doi.org/10.1016/ S1473-3099(10)70079-7

El-Dein, N.A., El-Deen, N.M.A., Tolba, M.S., ElShatoury, H.E., Awad, A.G., Ibrahim, K.M. and Mohamed, A.F. (2017). Probiotic Properties and Bile Salt Hydrolase Activity of Some Isolated Lactic Acid Bacteria. Egyptian Journal of Microbiology, 52 (1), 87-100. https://doi.org/10.21608/ ejm.2017.1336.1025

Emmanuel, A.N., Oliver, N.O. and Angela, U.N. (2016). Using Plant Materials for Treatment of Malaria in Imo State, Nigeria. American Journal of Life Science Researches, 4(2), 67-71. https://doi.org/10.20286/ ajlsr-040287

Fabbri, C., De-Cássia, M.N.R. and Lalwani, P. (2013). Lipid peroxidation and antioxidant enzymes activity in Plasmodium vivax malaria patients evolving with cholestatic jaundice. Malaria Journal, 12(1), 315. https://doi.org/10.1186/1475-2875-12-315

Fardet, A. and Rock, E. (2017). In vitro and in vivo antioxidant potential of milks, yoghurts, fermented milks and cheeses: a narrative review of evidence. Nutrition Research Reviews, 31(1), 1-19. https:// doi.org/10.1017/S0954422417000191

Gahruie, Hashem, H., Eskandari, Hadi, M., Mesbahi, G. and Hanifpour, A.M. (2015). Scientific and
Technical Aspects of Yogurt Fortification: A Review. Food Science and Human Wellness, (4), 18. https://doi.org/10.1016/j.fshw.2015.03.002

Gjorgievski, N., Ansley, N.M., Angus, B.J., Nosten, F. and Price, R.N. (2015). Determination of The Antioxidant Activity in Yogurt. Journal of Hygienic Engineering and Design, 8, 88-92.

Gomes, Q.B.A., Da-Silva, L.F.D. and Gomes, Q.A.R. (2015). N-acetyl cysteine and mushroom Agaricus sylvaticus supplementation decreased parasitaemia and pulmonary oxidative stress in a mice model of malaria. Malar Journal, 14(1), 1-12. https:// doi.org/10.1186/s12936-015-0717-0

Holvik, S.L. (2013). Introduction Macronutrient Nutritional Composition of Goat milk. Happy Days Dairies, p. 1-12. Canada: Happy Days Diaries

Isah, M.B. and Ibrahim, M.A. (2014). The role of antioxidants treatment on the pathogenesis of malarial infections: A review. Parasitology Research, 113(3), 801-809. https://doi.org/10.1007/ s00436-014-3804-1

Khalid, M., Alam, R., Khan, S. and Prakash, V. (2013). Oxidative Stress Marker and Antioxidant Status in Falciparum Malaria in Relation to the Intensity of Parasitaemia. International Journal of Biological and Medical Research, 3(1), 3469-3471.

Lad, S.S., Aparnathi, D.K., Mehta, B. and Velpula, S. (2017). Goat milk in Human Nutrition and Health A Review. International Journal of Current Microbiology and Applied Sciences, 6(5), 17811792. https://doi.org/10.20546/ijcmas.2017.605.194

Mahdi, C., Untari, H., Padaga, M.C. and Raharjo, S.J. (2018). The characterization of bioactive peptide of goat milk fermented to activities as antihypercholesterolemia. International Food Research Journal, 25(1), 17-23

Mala, M., Imam, M. and Hassan, K. (2016). Interaction between parasite and vector for Malaria disease transmission-a review on Malaria. Progressive Agriculture, 27(2), 168-174. https://doi.org/10.3329/ pa.v27i2.29327

Moreno-Fernandez, J., Alférez, M.J.M., López-Aliaga, I. and Javier, D. C. (2019). Protective effects of fermented goat milk on genomic stability, oxidative stress and inflammatory signalling in testis during anaemia recovery. Science Report, 9, 2232. https:// doi.org/10.1038/s41598-018-37649-6

Mota, M.M. and Mello-Vierra, J. (2019). Parasitism: Anopheles Mosquitoes and Plasmodium Parasites Share Resources. Current Biology, 29(3), 632-634. https://doi.org/10.1016/j.cub.2019.05.030

Muniandy, P., Shori, A.B. and Baba, A.S. (2016). 
Influence of green, white and black tea addition on the antioxidant activity of probiotic yogurt during refrigerated storage. Food Packgaing and Shelf Life, 8, 1-8. https://doi.org/10.1016/j.fps1.2016.02.002

Nakagawa, H. and Miyazaki, T. (2017). Beneficial effects of antioxidative lactic acid bacteria. AIMS Microbiology, 3(1), 1-7. https://doi.org/10.3934/ microbiol.2017.1.1

Ngatidjan. (2006). Petunjuk Laboratorium Metode Laboratorium Dalam Toksikologi. Yogyakarta: Fakultas Kedokteran Universitas Gadjah Mada. [In Bahasa Indonesia].

Nguyen, L. and Hwang, E.S. (2016). Quality characteristics and antioxidant activity of yogurt supplemented with aronia (Aronia melanocarpa) juice. Preventive Nutrition and Food Science, 21(4), 330-337. https://doi.org/10.3746/pnf.2016.21.4.330

Okpe, O., Habila, N., Ikwebe, J., Upev, V.A., Okoduwa, S.I.R. and Isaac, O.T. (2016). Antimalarial Potential of Carica papaya and Vernonia amygdalina in Mice Infected with Plasmodium berghei. Journal of Tropical Medicine, 2016, 8738972. https:// doi.org/10.1155/2016/8738972

Park, Y.W. (2010). Goat milk: Composition, Characteristics. In Pond, W.G. and Bell, N. (Eds.) Encyclopedia of Animal Science. 2nd ed. Boca Raton, FL: CRC Press.

Percário, S., Moreira, D.R., Gomes, B.A.Q. and Ferreira, M.E.S. (2012). Oxidative Stress in Malaria Review. International Journal of Molecular Sciences, 13(12), 16346-16372. https://doi.org/10.3390/ ijms131216346

Polak-Berecka, M., Wasko, A., Szwajgier, D. and Choma, A. (2013). Bifidogenic and antioxidant activity of exopolysaccharides produced by Lactobacillus rhamnosus $\mathrm{E} / \mathrm{N}$ cultivated on different carbon sources. Journal of Microbiology, 62, 181189. https://doi.org/10.33073/pjm-2013-023

Queiroz, V.V.O., Assis, A.N.O. and Junior, H.C.R. (2013). Protective effect human lactoferrin in the gastrointestinal tract. Revista Paulista de Pediatria, 31(1), 90-95. https://doi.org/10.1590/S010305822013000100015

Sabeena, F.K.H., Baron, C.P., Nielsen, N.S. and Jacobsen, C. (2010). Antioxidant activity of yoghurt peptides: Part 1-in vitro assays and evaluation in $\omega-3$ enriched milk. Food Chemistry, 123(4), 1081-1089. https://doi.org/10.1016/j.foodchem.2010.05.067

Shasteen, M.A., Lebeis, W.S. and Schmidt, N. (2015). Lessening Malaria Parasite Burden with Yogurt. Microbiology Publications and Other Works. Retrieved from Tennessee Research and Creative
Exchange (TRACE) website: http:// trace.tennessee.edu/utk_micrpubs/74

Shu, G., Shi, X., Chen, L., Kou, J., Meng, J. and Chen, H. (2018). Antioxidant Peptides from Goat milk Fermented by Lactobacillus casei L61: Preparation, Optimization, and Stability Evaluation in Simulated Gastrointestinal Fluid. Nutrients, 10(6), 797. https:// doi.org/10.3390/nu10060797

Subdit Malaria Direktorat KR. (2018). Buku Saku Tatalaksana Malaria 2018. Indonesia: Kemenkes RI. [In Bahasa Indonesia].

Tafor, D., Djunaidi, A., Wasityastuti, W. and Sholikhah, N.E. (2013). Tumor Necrosis Factor-Alpha (TNFAlpha) and Intercellular Adhesion Molecule-1 (ICAM-1) Expression of Plasmodium berghei Infected Swiss Mice Treated with Red Fruit (Pandanus conoideus Lam) Ethanol Extract. Tropical Medicine Journal, 3(2), 155-165.

Torres, K., Bachman, C.M., Delahunt, C.B., Jhonatan, A.B., Freddy, A., Dionicia, G.V., Stephane, P., Courosh, M., Shawn, K. McG., Clay, M.T., Travis, O., Liming, H., Mayoore, S.J., Victoria, M.H. and David, B. (2018). Automated microscopy for routine malaria diagnosis: a field comparison on Giemsastained blood films in Peru. Malaria Journal, 17, 339. https://doi.org/10.1186/s12936-018-2493-0

Tyagi, A.G., Tyagi, R.A., Choudhary, P.R. and Shekhawat, J.S. (2017). Study of antioxidant status in malaria patients. International Journal of Research in Medical Sciences, 5(4), 1649-1654. https://doi.org/10.18203/2320-6012.ijrms20171281

Villarino, F.N., Lecleir, R.G., Denny, E.J., Dearth, P.S., Harding, L.C., Sloan, S.S., Jennifer, L.G., Shawn, R.C., Steve,n W.W. and Nathan, W.S. (2016). Composition of the gut microbiota modulates the severity of malaria. Proceedings of the National Academy of Sciences, 113(8), 2235-2240. https:// doi.org/10.1073/pnas.1504887113

WHO. (2015). Guidelines for the treatment of malaria. $3^{\text {rd }}$ ed. Geneva: WHO.

Yangilar, F. (2013). As a Potentially Functional Food: Goats' Milk and Products. Journal of Food and Nutrition Research, 1(4), 68-81. doi:10.12691/jfnr-14-6

Zapata, C.R., Singh, A., Pezeshki, A., Nibber, T. and Chelikani, K.P. (2017). Whey Protein Components Lactalbumin and Lactoferrin - Improve Energy Balance and Metabolism. Scientific Reports, 7, 9917. https://doi.org/10.1038/s41598-017-09781-2 